\title{
ENTRE CASTANHAS, OURO E AS FONTES PARA O ENSINO DA HISTÓRIA LOCAL DO SUL E SUDESTE DO PARÁ
}

\author{
Among Brazil nuts, gold and historical sources for the teaching \\ of local history about the south and southeast of Pará
}

\section{Carlo Guimarães Monti ${ }^{1}$ Yana Brito Vieira** Gabriela Barreto das Neves***}

\begin{abstract}
Resumo: $\mathrm{O}$ artigo proposto tem por foco a organização e preparação de um conjunto de fontes primárias que fazem parte de dois acervos: Arquivo Histórico Municipal de Marabá "Manoel Domingues" e do Centro de Referência em História e Memória do Sul e Sudeste do Pará, os quais tem a função de preservar a documentação histórica e jurídica do município de Marabá e resguardar a memória histórica/cultural escrita e visual dos povos da região. O trabalho com essa documentação visa separar e analisar uma parte desses acervos que esboce os sujeitos histórico que fizeram parte da época estudada, mas que por serem percebidos como grupos de pouco poder político e econômico foram esquecidos. Os acervos em questão, possibilitam adentrarmos nas relações que tiveram vez em busca do "outro". A preparação desse material para ser utilizado em sala de aula, no ensino de história tem por fim ser trabalhado em paralelo com materiais didáticos e ampliar a visão sobre um período histórico e dar voz a outros personagens em um processo de desconstrução de poderes constituídos no sul e sudeste do Pará.
\end{abstract}

Palavras-chave: Ensino de História; Fontes históricas; Marabá.

\begin{abstract}
The article focuses on the arrangement of a set of historical sources that compose two collections located in both the Municipal Historic Archive of Marabá Manoel Domingues and the Reference Center on History and Memory of the South and Southeast of Pará. We aim to analyze parts of those collections related to historical forgotten social groups with no political or economic power. The organization of these historical sources may give cause to their use in teaching history along with others didactic materials, expanding, by giving voice to forgotten characters and questioning the political and economic local constituted powers, the historical interpretations.
\end{abstract}

Keywords: History teaching; Historical sources; Marabá city.

\section{Introdução}

A pesquisa em questão é realizada com a proposição de apresentar ações para as problemáticas enfrentadas pelo ensino de história na educação básica, buscamos contribuir com a indicação de recursos que podem ser apontados como eficientes para o ensino de história em sala de aula.

\footnotetext{
1 Professor adjunto na Universidade Federal do Sul e Sudeste do Pará (UNIFESSPA). Doutor em história pela Universidade Estadual Paulista Julio de Mesquita Filho (UNESP). E-mail: carlogmonti@gmail.com

** Graduanda em História pela Unifesspa/Marabá. Bolsista PIBIC/PNAES.Edital PROPIT 02/2018.

*** Graduanda em História pela Unifesspa/Marabá. Bolsista PIBIC/CNPq.Edital PROPIT 11/2018.
} 
A tarefa da história, segundo Janaína dos Santos Correia (2012), seria a de nos proporcionar um senso de identidade ao mesmo tempo em que nos possibilita recursos para dialogarmos e nos relacionarmos com o outro, com a diversidade e a pluralidade de experiências e vivências que nos cercam. Considerando o objetivo do ensino da História como sendo o de incentivar o pensamento crítico e a construção de identidades, o uso de diferentes fontes em sala de aula é uma estratégia para garantir uma educação que busque a valorização da diversidade e das diferentes culturas.

Este artigo tem por objetivo realizar um procedimento analítico para a utilização de documentos no ensino de história, soma-se a esse conjunto de experiências e estudos, o trabalho com fonte em sala de aula. Propomos trabalhar a utilização de documentos no ensino de história local como uma estratégica para que os professores superem as limitações do livro didático, sem a pretensão de substituir esse material. Além de, lidarmos com o desinteresse de alguns alunos e, com o questionamento que muitos realizam, sobre o porquê de se estudar história?

Assim, queremos contribuir para as pesquisas em relação ao uso de fontes no ensino de história na educação básica. Por compreender que, o uso de documentos escritos em sala de aula é um importante elemento para o desenvolvimento cognitivo do estudante.

A proposta em que estamos trabalhando visa o estudo da história local e regional, a partir dos acervos existentes na Fundação Casa Da Cultura de Marabá e do "Centro de Referência em História e Memória do Sul e Sudeste do Pará”, localizado na UNIFESSPA - Universidade Federal do Sul e Sudeste do Pará, na cidade de Marabá-PA².

Para que se possa trabalhar em sala algumas referências locais dessa história, as fontes disponibilizadas estão sendo selecionadas a partir do eixo temático de migração para a região Sudeste e Sul do Pará gerado pelas atividades de exploração dos recursos naturais da Amazônia e pelos grandes projetos de desenvolvimento da região, que acabaram por afunilar-se atualmente nas atividades de desmatamento, de pastagem, de mineração e de extração de ouro.

Os documentos vêm sendo explorados há algumas décadas como fontes para a pesquisa histórica. No entanto sua utilização como recurso pedagógico para o ensino de história na educação básica é uma discussão recente, o que requer um debate a respeito dos métodos aplicados e das possibilidades a serem trabalhadas.

A história sempre se apresentou como um espaço de disputa entre diversas correntes teóricas que defendiam cada uma a seu modo a utilização de documentos, de métodos de trabalho e áreas de interesse. Entre tais correntes é importante destacar a Escola Positivista para a discussão a respeito de documentos e fontes históricas.

Essa corrente estabeleceu o "documento primário" como fonte irrefutável do passado, ou seja, acreditava que através dos documentos era possível chegar a uma verdade absoluta sobre o passado e que cabia ao historiador o papel de compilar e organizar os documentos cronologicamente (Neto, 2001).

Para os positivistas não havia separação entre documento e fonte, ambos eram iguais e equivalentes. Dessa forma, os documentos oficiais eram considerados as únicas fontes válidas para a construção da história (Caimi, 2008) caracterizando assim, um período no qual as produções historiográficas estavam ligadas ao registro da vida de grandes figuras sociais, da economia e da política.

\footnotetext{
2 Essa pesquisa faz parte do projeto de título "Procedimento analítico para a utilização de documentos no ensino de história" que foi comtemplado com quatro bolsas PIBIC/Unifesspa/PROPIT, sendo duas CNPq, uma PNAES e outra FAPESPA a quem agradecemos.
} 
Como André Neto (2001) aponta esta corrente teve grandes consequências para o ensino da história, já que por muito tempo a disciplina limitou-se a ensinar e amemorizar datas, nomes e acontecimentos da vida de reis, imperadores, vencedores e acontecimentos políticos valorizando sempre o acontecimento em prejuízo ao processo.

Contrapondo-se a isso, no século XX surge na França a revista 'Annales d'Histoire Économique e Socieale'. Entre os diversos objetivos que os Annales possuíam havia o de modificar o conceito de fonte, tirando dele o caráter de detentor da verdade absoluta. Eles também queriam que o material escrito deixasse de ser visto como algo inofensivo e passasse a ser enxergado como fruto de processos da construção humana, carregados de ideologias e intenções de acordo com o lugar e tempo no qual foi produzido (Neto, 2001).

No âmbito do ensino, os Annales contribuíram de forma significativa para a construção de métodos de ensino pautados na interdisciplinaridade, na pluralidade de fontes e em novas perspectivas temáticas, direcionando o olhar da disciplina para aspectos da vida social que ficavam reservados antes a outras áreas do conhecimento (Pereira e Seffner, 2008).

A partir da perspectiva dos novos historiadores (LE GOFF, 2005) e, sobretudo, em função da contribuição de Michel Foucault (1987), o documento se torna monumento, ou seja, ele é rastro deixado pelo passado, construído intencionalmente pelos homens e pelas circunstâncias históricas das gerações anteriores. O documento não é mais a encarnação da verdade, nem mesmo pode ser considerado simplesmente "verdadeiro" ou "falso" (Pereira e Seffner; 2008; p. 115).

\section{Ensino de história e o uso de fontes em sala de aula.}

As concepções em torno da história como uma disciplina escolar produzem-se em um ambiente de disputa em que diferentes correntes teóricas se contrapõem. As principais correntes teóricas que influenciam o ensino de história hoje são datadas do século XX, como a Escola dos

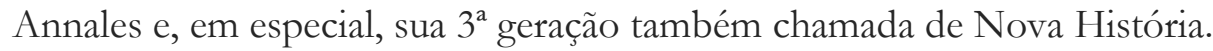

Deste modo, as propostas da Escola dos Annales foram cruciais para a construção de uma nova forma de fazer e ensinar história, considerando seu caráter de ruptura com a Escola Metódica e o Positivismo.

No Brasil os debates a respeito do ensino de história são aprofundados no século XX a partir das décadas 1980 e 1990, no pós-ditadura em que se apresenta uma constante preocupação em afirmar a necessidade de formar alunos com pensamento crítico e autonomia intelectual (Ribeiro, 2015).

Considerando que o objetivo do ensino de história regional e local, por exemplo, é o de auxiliar na construção de identidades, pode-se constatar que o livro didático - confeccionado de forma generalizante - não oferece sozinho suporte teórico e metodológico suficiente para trabalhar as especificidades que fazem parte da rotina dos alunos, e sua interação social a partir da espacialidade vivida. A falta de ligação da história ensinada com os elementos da vivência dos alunos tende a proporcionar uma aula que não estimula o interesse, gerando até mesmo questionamentos a respeito da utilidade da própria história e do porquê de estudá-la. Desse modo, o uso de fontes para o ensino de História em paralelo ao livro didático pode ser bem-visto como recurso auxiliador do processo de ensino aprendizagem plural e inclusivo.

Durante muito tempo as fontes históricas estiveram engessadas e limitadas a um determinado tipo de fonte, 
Contudo, a partir do momento que se constituiu uma concepção de história que começou a se interessar por toda a atividade, considerar que "tudo tem história" e todos os homens, independentemente da posição que ocupam na sociedade, de uma forma ou outra fazem parte do devir histórico, se abriu um leque de possibilidades para que os professores inovem na sua forma de trabalhar em sala de aula. (Rolim, 2002, p. 69).

O uso de fontes nos processos de ensino e aprendizagem não deve ser tratado como findado em si mesmo, o objetivo não é analisar as fontes de maneira externa à realidade que se vive em sala de aula, pelo contrário, a fonte deve ser utilizada visando atender às indagações e problemáticas lançadas por alunos e professores (Schmidt e Cainelli, 2009). Dessa forma, a fonte em sala de aula auxilia no processo de ensino dos alunos e da sua compreensão de si, de suas identidades, do local em que vivem e do meio no qual pode intervir diretamente através de suas ações.

O processo de diversificação das fontes leva a uma dinamização das práticas de ensino e aprendizagem, dessa forma o aluno tem a possibilidade de entrar em contato com o conteúdo histórico através de um processo muito mais dinâmico e atrativo. Do mesmo modo, o uso de fontes também auxilia na aproximação da realidade do aluno, possibilitando a discussão e o debate de diferentes visões, ao proporcionar o maior estímulo diante da complexidade cultural e da experiência histórica do homem (Correia, 2012). Esses processos instigam os estudantes na construção de um olhar e do pensamento crítico a respeito das relações sociais que os cercam e das dinâmicas históricas que lhe afetam, levando a construção daquilo que pode ser chamado de consciência histórica.

Problematizar a história em sala de aula consiste assim em mobilizar conteúdos que não tenham caráter estático, desvinculados no tempo e no espaço, como fins em si mesmos, mas que permitam aos estudantes compararem as situações históricas em seus aspectos espaçotemporais e conceituais, promovendo diversos tipos de relações pelas quais seja possível estabelecerem diferenças e semelhanças entre os contextos, identificarem rupturas e continuidades no movimento histórico e, principalmente, situarem-se como sujeitos da história, porque a compreendem e nela intervém (Caimi apud Correia, 2012, p. 197-198).

Janaína dos Santos Correia trás o pensamento da historiadora Flávia Eloisa Caimi justamente para exemplificar a discussão que se faz a respeito da relação que pode ser criada entre os alunos e a história através do uso de fontes em sala de aula, possibilitando criarem uma relação diferente com suas próprias vidas.

Quando Hardalla Santos do Vale, Eduardo Arriada e Lisiane Costa Claro (2010) fazem uma discussão a respeito do uso da imprensa como possibilidade de fonte de conhecimento histórico, eles exploram a perspectiva de que o papel das fontes não se limita apenas a compreensão de uma noção de tempo, mas que auxiliam na compreensão da complexa rede de fatores que fazem parte da história - como as relações sociais e, a influência de interesses econômicos e políticos nos processos históricos.

A compreensão de tais fatores no passado auxilia a maneira de assimilar os mesmos no presente, não na perspectiva de que a história possui a capacidade de prever o futuro, mas na perspectiva de que os alunos passam a ter contato criticamente com os processos que influenciam na dinâmica de suas vidas. Como, por exemplo, acordos políticos do passado que auxiliam na interpretação das relações políticas do presente, situações de marginalização, distribuição espacial de determinados grupos sociais - em determinados espaços urbanos. Todos estes são aspectos que podem ser compreendidos no presente através de um viés que auxilie na compreensão das relações históricas. 
Fabiana de Paula Guerra e Leudjane Michelle Viegas Diniz (2007) fazem uma discussão a respeito do uso das fontes, em que, evidenciam a possibilidade de ensino mais interativo e prazeroso, e que tenha significado para a vida do estudante. Pois, quando o aluno é inserido no processo de construção do conhecimento ele participa de forma mais ativa da aula evitando distrações paralelas e estimulando o interesse no estudo dos conteúdos abordados na aula. Dessa maneira, o uso de diversas fontes tem a contribuir tanto na construção de conceitos históricos e aprendizagens quanto no processo de bem-estar dentro do ambiente escolar.

A utilização do documento no ensino de história deve estar em concordância com uma preocupação metodológica do professor, tendo em vista que diferente do livro didático o documento não possui um caráter pedagógico, não é o objetivo para o qual foi criado (Chaves, 2013). Assim, é importante lembrar que a relação do documento como fonte para o ensino, exige uma preparação por parte do professor, visualizando com atenção o melhor momento e a forma como este deve ser abordado.

Outra perspectiva importante na utilização das fontes para o ensino de história é a concepção de história na academia e no ensino. Os documentos podem ser trabalhados em ambos os espaços, entretanto é importante ter em vista que cada ambiente demanda uma abordagem diferente, já que, cada um apresenta um objetivo de trabalho diferente.

O objetivo da história na academia é muito mais de produzir contribuições para as discussões historiográficas enquanto na escola a história parte do pressuposto de colaborar para a formação dos alunos como cidadãos, ou seja, a escola não pretende formar historiadores (Pereira e Seffner, 2008).

Uma problemática debatida é a de que a escola está distante das inovações historiográficas, para compreender essa questão é importante visualizar o tempo histórico de cada um. O tempo histórico da escola aproxima-se muito mais do tempo histórico do senso comum do que da pesquisa e, isso ocorre porque os alunos e, o próprio professor estão na maioria dos casos inseridos em uma cultura escolar com um convívio muito maior com a memória coletiva, em detrimento das inovações historiográficas (Pereira e Seffner, 2008).

Flávia Eloisa Caimi (2008) defende que os campos escolar e acadêmico possuem cada um suas próprias dinâmicas de construção que se relacionam com diversos fatores. Sendo assim, é importante respeitar as particularidades das abordagens de cada um dos ambientes, tendo em vista que quando um ultrapassa o outro gera problemas. Não é papel da escola formar historiadores.

Seguindo a linha de pensamento defendida por Pereira e Seffner (2008) o uso de documentos pode contribuir para a criação de uma empatia dos alunos com sua própria realidade, já que o documento pode ser visto e interpretado como um meio de construir o conhecimento e não um fato acabado em si, partindo da interrogação, interpretação e problematização (Orta, 2007).

Marieta Pinheiro de Carvalho (2017) também defende que o uso dos documentos em sala de aula contribui para a formação de um pensamento crítico, além de auxiliar na compreensão de conteúdos tornando-os mais concretos quando eles estiverem demasiado abstratos. Em concordância, Anunciação e Sperandio (2012) argumentam que o uso desses recursos possibilita ao aluno criar certa familiaridade com os eventos passados colaborando para o desenvolvimento de um raciocínio histórico.

O aluno não pode ser visto como um mero receptor do conhecimento histórico, mas um agente de construção de tal conhecimento (Neto, 2001). Além disso, o uso dos documentos não pode ser feito de maneira a servir apenas como um reforço para o que o professor disse ou, como um atestado de verdade (Pereira e Seffner, 2008), essa é uma abordagem problemática que não 
contribui para a construção do pensamento histórico do estudante.

A utilização de documentos com material didático exige um compromisso pedagógico do professor, tendo em vista que deve utilizar por acreditar na eficácia e importância e, não apenas como forma de dinamizar a aula sem de fato contribuir para um cenário de construção do conhecimento (Pereira e Seffner, 2008). Pois com defendeu Neto (2001) a adoção desses recursos tem condições de estimular a curiosidade e o desejo de conhecimento dos alunos se trabalhado da forma correta.

A primeira indicação metodológica que se faz para o trabalho entre alunos e documentos no ensino de história é fomentar a desconfiança, não de forma que venha a atestar sua falsidade, mas de maneira a olhá-lo como um monumento que foi ordenado, classificado e recebeu novos significados por diversas gerações ao longo do tempo no seu processo de criação e preservação (Pereira e Seffner, 2008).

\section{Prática metodológica e o trabalho com fontes históricas em sala de aula}

A pesquisa focou sua busca por fontes que sirvam como materiais de suporte para o trabalho do professor em sala de aula e que venham a ser utilizadas em paralelo com os livros didáticos.

Uma das características do trabalho com fontes no ensino de história é o de aproximar os conceitos históricos ao cotidiano dos alunos, fornecendo condições para assimilar o conhecimento e formar um pensamento crítico a respeito de suas próprias vidas. Desse modo, muitos pesquisadores e educadores propõem como estratégia trazer para sala de aula documentos dos estudantes ou, de seus familiares que possam ser relacionados ao contexto histórico trabalhado, não com o objetivo de se prender à história familiar dos alunos, mas relacionar seus aspectos pessoais a uma história mais ampla (Orta, 2007).

É preciso considerar o importante papel do docente no desenvolvimento do trabalho com fontes em sala de aula, principalmente por que as fontes, em si, não possuem nenhuma capacidade de transformar ou inovar o sistema educacional, elas são apenas instrumentos nas mãos de um professor e do seu grau de compromisso com um ensino inclusivo e diverso (Neto, 2001).

Uma possibilidade de trabalho com o uso de fontes é o de atividades dentro da própria sala de aula - sendo em muitos casos o mais cômodo para a maioria dos professores. Em tais atividades a estratégia defendia por grande parte dos educadores é o de analisar as fontes combinando diferentes formas, incentivando a criatividade e criticidade dos alunos, assim buscando torná-los protagonistas de todo o processo.

Para iniciar o trabalho em sala de aula, muitos defendem que o professor faça apresentação aos discentes da temática a ser explanada situando-os no contexto histórico, bem como no papel das fontes escolhidas para serem exploradas em aula. De tal modo, que o estudante possa compreender tanto o conteúdo da disciplina quanto os motivos pelos quais as fontes foram selecionadas, além das possibilidades de aprendizagem que elas abarcam. Além disso, Rogério de Almeida (2017) sugere que o professor esteja munido de aspectos importantes para compartilhar com os alunos como, por exemplo, dados técnicos sobre as fontes.

Geralmente os trabalhos em sala de aula possuem a característica de serem realizados em duplas ou grupos, o que proporciona uma reflexão em conjunto em que os discentes passam a ter contato com as diversas ideias de seus colegas que podem convergir ou divergir - em ambos os casos é positivo para a aprendizagem.

Ana Raquel Portugal (2015) demonstra essa situação ao formar grupos para analisar um 
mesmo texto e, fomentar um debate geral com a turma inteira, assim pode-se perceber que o trabalho de investigar a mesma fonte em grupo é importante para que os alunos reúnam as suas percepções e obtenham uma visão ampla a respeito da temática da aula.

Esses projetos fazem uso de recursos como análise de documentos, seleção de objetos de estudo pelos próprios alunos, avaliação de conhecimentos prévios, desenvolvimento de trabalhos de campo: entrevistas, captura de imagens, pesquisas para tipos de fontes de diferentes propostas e visitas a espaços de memória. Em outra etapa temos a análise do conhecimento dos estudantes, geralmente através de processos avaliativos escritos (resenhas, atividades, provas), buscando identificar os pontos de avanço na aprendizagem de conceitos e dificuldades ainda apresentadas (Nascimento, 2015). Em concordância Bittencourt (2008) defende que sejam possibilitados espaços para que os alunos realizem debates sobre as fontes e os temas e, que sintetizem os conhecimentos adquiridos por meio da produção de textos, para incentivar o desenvolvimento de habilidades de escrita.

Analisando as diversas possibilidades de fontes que podem vir a ser utilizadas em paralelo ao livro didático é possível explorar algumas contribuições metodológicas.

André Neto (2001) defende que o aluno precisa ser visto e colocado na posição de protagonista dos processos de ensino aprendizagem, o uso de documentos auxilia em tal empreitada por possibilitar o contato direto com a realidade dos alunos e de relacioná-los ao passado. Exemplificando esse processo de protagonismo do aluno temos a seguinte perspectiva ao debater o uso de documentos familiares no ensino de História:

Entre as precauções com o uso de documentos no ensino de História, devemos tomar cuidado em não utilizar o documento como um atestado da verdade, conferindo a ele uma posição inquestionável. É importante analisar os documentos históricos como sendo passíveis de problematizações, questionamentos, dúvidas e desafios para que esses proporcionem o desenvolvimento de uma visão crítica por parte dos alunos (Lara, 2008). Sendo assim, é preciso buscar, questionar os fatores em torno do documento, em especial sua origem: quem o escreveu, com que finalidade e por que - em meio a tantos outros - foi digno de preservação (Neto, 2001). Em concordância com esse processo de incentivo à pesquisa e a curiosidade do aluno é importante valorizar e compreender o processo de preservação dos documentos (Lara, 2008), considerando que muitos documentos são produzidos, mas poucos são preservados do esquecimento.

Elisgardenia Chaves (2013) defende a exploração de duas dimensões ao trabalhar com documentos no ensino de história. A primeira dimensão seria a descritiva e se refere à identificação dos processos históricos e dos sujeitos que protagonizam aquelas ações no tempo e a dimensão explicativa que se refere às abordagens do tema e às visões teórico-metodológicas da historiografia sobre o tema. Esse processo é de coleta e percepção de informações cruciais para compreender o documento, o contexto no qual foi criado e as concepções que se fazem a respeito do período em questão.

Neto (2001) também defende em sua abordagem metodológica que o professor deve oferecer ao aluno recursos que o instigue a questionar o documento identificando assim características como emissor, receptor, condições de produção do documento, relações interpessoais, os antecedentes da criação daquele documento e seu sentido para o momento em que foi criado. Dessa maneira, o aluno ao fazer esse processo de investigação aguça sua curiosidade para a pesquisa ao mesmo tempo em que se aproxima do conhecimento histórico.

Da mesma forma, Valéria Oliveira (2002) defende que os questionamentos são de fundamental importância para a relação dos alunos com os documentos em sala de aula. 
No primeiro grau, o aluno pode atuar como um investigador da pesquisa realizada pelo historiador. O objetivo da proposta é fazer como que o aluno perceba que ele pode dialogar com as fontes históricas, assim como fez o historiador, que é possível retirar conclusões e que estas conclusões não serão as mesmas para todos do grupo, assim como não são as mesmas para todos os historiadores. Ele poderá construir uma série de hipóteses a respeito, relacionar causas e efeitos, temporalizar, ou seja, raciocinar sobre o assunto em questão. (Oliveira, 2002, p. 226).

O historiador defende que o aluno deve buscar a resposta para perguntas que lhe aproximem de características fáceis a respeito do documento como, por exemplo, sua finalidade, temporalidade, espacialidade, o desenrolar dos fatos, os sujeitos que compõem esse evento registrado e as consequências - quando for o caso.

A maioria do historiadores que trabalham com documentos para o ensino de história, concorda que instigar a curiosidade do aluno, fazendo-o ir à busca de informações nos documentos, é de grande importância, pois esse processo estimula a construção de um conhecimento histórico, além de contribuir para o seu desenvolvimento como cidadão que possui a habilidade de realizar uma leitura crítica.

É importante aliar o protagonismo dos alunos como agentes de construção de conhecimento, com a utilização de recursos - como os documentos - que instigam o pensar criticamente e o compromisso didático pedagógico dos professores para a realização de aulas que atendam ao propósito da construção do conhecimento histórico.

Sendo assim nesse artigo trabalhamos duas propostas de análise de documentos que dão conta de momentos distintos da história local e regional do sul e sudeste do Pará. O primeiro documento diz respeito ao período de exploração da Castanha na região de Marabá, que teve seu auge entre as décadas 1920 e 1980. Já o segundo documento está ligado ao garimpo de Serra Pelada e seus processos de disputas pelo direito à exploração do território em busca de ouro, datando o ano 1984.

O primeiro documento utilizado, diz respeito ao período da exploração da Castanha na região de Marabá no estado do Pará. É uma ação judicial guardada no "Centro de Referência em História e Memória do Sul e Sudeste do Pará”, localizado na UNIFESSPA - Universidade Federal do Sul e Sudeste do Pará, na cidade de Marabá-PA. Tal ação judicial foi registrada na comarca de Marabá na década 1970, e trata de situações conflitantes ligadas às relações de trabalho em torno da exploração da castanha na região do munícipio de Marabá.

O documento que ora passamos a chamar de "Processo", ver imagem $1^{3}$, é uma ação judicial movida por Angelo Cruz, um carpinteiro, contra Marcio Pereira, que trabalha como extrator de castanha. Na primeira parte do documento são apresentados os dois sujeitos, através de informações como profissão, naturalidade, estado-civil e endereço. Já na segunda parte, é exposto no documento que Angelo Cruz prestou serviço de carpintaria trabalhando por 42 dias na manutenção de barcos utilizados para o transporte da castanha, no lugar chamado Itaipavas, ponto "Comarú", no entanto não recebeu pagamento pelo trabalho exercido. Dessa forma, a ação judicial requer o pagamento de uma indenização no valor de Cr\$504,000 por parte de Angelo Cruz. Além disso, as despesas advocatícias são requeridas em $20 \%$ sobre o valor da multa exigida.

\footnotetext{
${ }^{3}$ Os nomes das pessoas envolvidas no processo 1 foram modificados, o nomes utilizados são fictícios.
} 


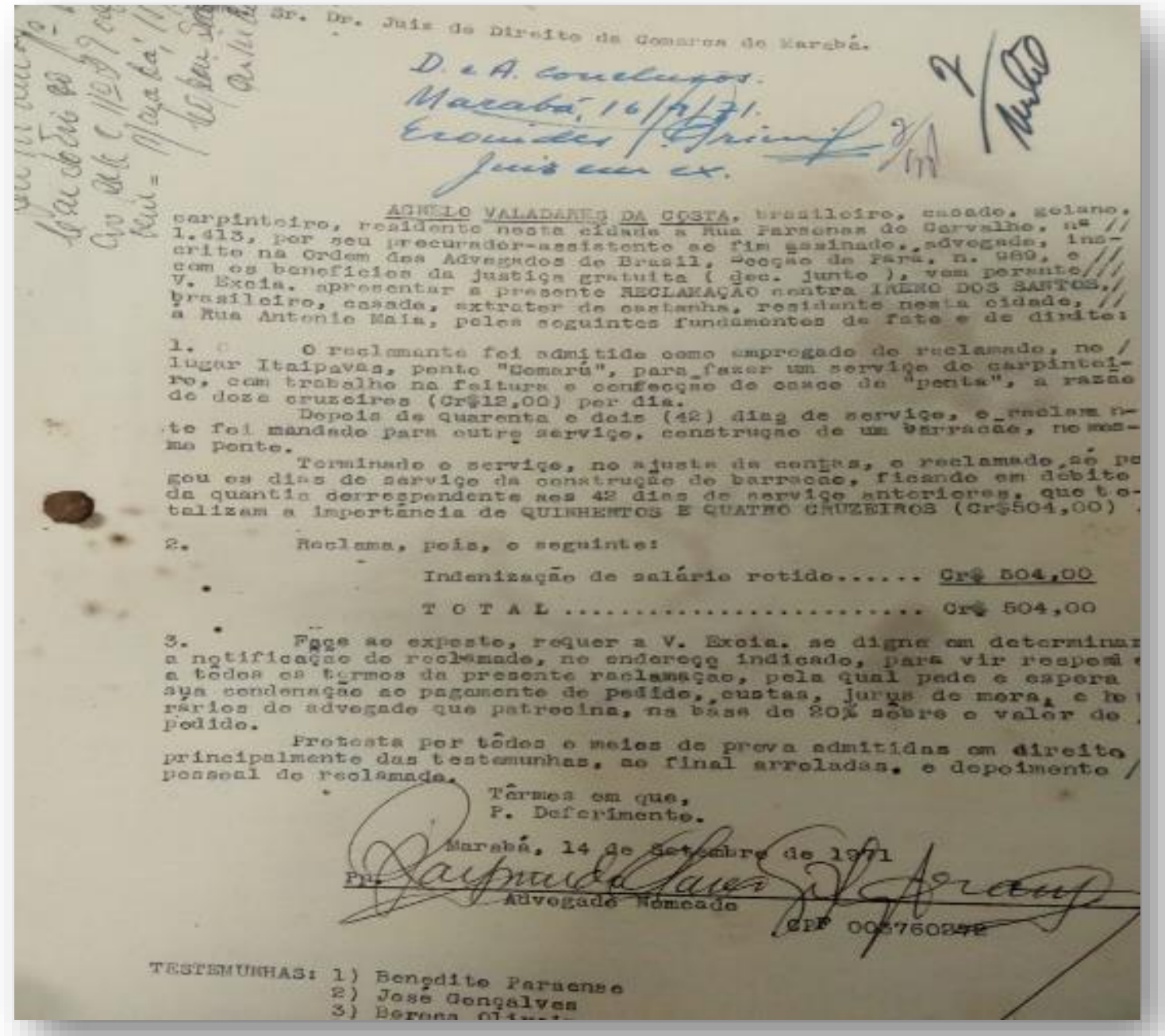

Fonte: "Processo". Acervo do Centro de Referência em História e Memória do Sul e Sudeste do Pará, Unifesspa, Campus 1 - Marabá-PA.

Já a segunda fonte trabalhada foi encontrada sob a guarda da "Fundação Casa da Cultura de Marabá”, que é uma instituição de pesquisa que atua ativamente na região há cerca de 33 anos, e possui um grande acervo documental do Sul e Sudeste do Pará, grande parte desse material encontra-se digitalizada no seu banco de dados. A fonte que selecionamos do acervo, foi denominada como "Jornal" e foi retirada do jornal "O Liberal", publicado no dia 09 de novembro de 1984. O documento é dividido em duas partes, a primeira afirma que alguns policiais foram agredidos fisicamente por garimpeiros, frisando a participação do diretor da cooperativa, que não permitiu a prisão dos agressores e que segundo a matéria do jornal também participou da agressão aos policiais. Só não ocorreu um problema maior porque os policiais não reagiram, mesmo estando armados. Na segunda parte do documento é apresentada a notícia sobre a retirada dos agentes policiais do garimpo, frisando a falta de segurança no local, ainda informa que havia apenas trinta agentes para controlar uma população de 50 mil homens que estavam vivendo em situações de extrema penúria e pobreza.

Quando se faz a opção pela proposta de trabalhar com fontes em sala de aula o professor 
deve tomar alguns cuidados, a seguir destacamos os principais pontos a serem observados.

Em um primeiro momento ao realizar a seleção de documentos para serem trabalhados em sala de aula é importante que o professor opte por fontes que possibilitem a problematização de temas naturalizados ou cristalizados historicamente pelo senso comum.

As fontes aqui apontadas indicam essa seleção: no caso do documento que nomeamos como "Processo", podemos utilizá-lo na perspectiva de trabalhar em sala de aula a formação da região de Marabá, as influências do ciclo de exploração da castanha para a formação e desenvolvimento econômico do munícipio, a partir da óptica de sujeitos até então pouco abordados pela historiografia da história do trabalho. Já com o documento que ora nomeamos como "Artigo de Jornal", ver Imagem 2, fica evidente a intenção de retratar o garimpeiro como um problema.

Por meio da análise do documento proposto pode-se compreender o processo de transição de uma narrativa construída a partir de um momento decisivo da expulsão dos garimpeiros de Serra Pelada, que é pautado por um acordo de interesses em que o garimpeiro deixa de ser "útil", e precisa ser descartado, incorrendo na questão: como descartar uma população de mais de 50 mil homens? A fonte permite que se pense na construção de uma narrativa que coloca o garimpeiro como um ser incivilizado, incontrolável, resumido a braços que servem apenas como números, denominados a partir de uma referência animalizada, em que se tornam comuns os "homens formigas", como assim eram chamados os que carregam sacos e que não tinham direito ao percentual da produção - os mesmos representam 90\% dos garimpeiros - eles ocupavam diversas funções a troco de algum salário, ou de algum ganho (Moura, 2008). O que também indica a ineficiência da extração do ouro e, uma miséria generalizada no garimpo, sempre se referindo ao garimpeiro como um mal acumulado que agora precisa ser encerrado.

O documento possibilita abordar em sala o imaginário que permanece na cabeça das pessoas a partir da criação da Serra Pelada, as histórias que comumente são repassadas a partir de uma visão crítica e contextualizada, frisando principalmente a construção do Sul e Sudeste do Pará a partir da década de 70, com seus diversos projetos desenvolvimentistas que se entrelaçam numa estrutura maior, contribuindo para o que é hoje a região. 


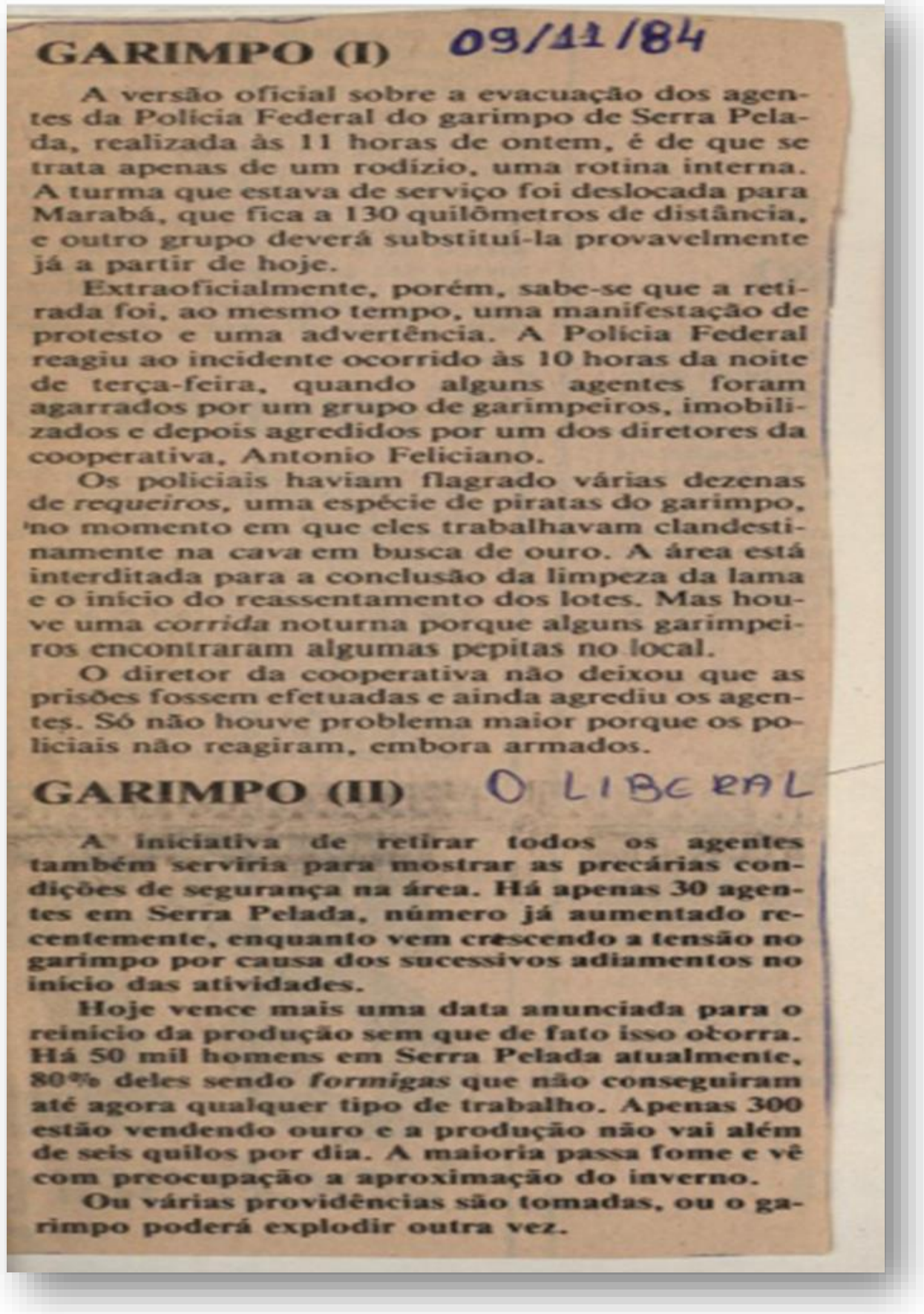

Fonte "Recorte". Acervo da "Fundação Casa da Cultura de Marabá". Arquivo Histórico Manoel Domingos.

Num segundo momento é importante levar em conta alguns critérios sobre a estrutura dos documentos a serem utilizados em sala de aula, entre eles temos: o estado de conservação, sua legibilidade; a clareza das informações que constam no documento de acordo com o nível de complexidade; a extensão do documento observando o tempo disponível para a realização da aula; o conceito substantivo que ele trás e que irá conduzir a um tema gerador de discussões. Seguindo a proposta a fonte "Processo" apresenta um bom estado de conservação, todo o corpo do texto 
contido no documento é possível de ser lido com clareza; as informações contidas são diretas, com uma linguagem e estruturação acessíveis a estudantes do ensino fundamental, algumas expressões são específicas do ambiente dos Castanhais, mas que podem ser facilmente provocadas pelo professor; o documento não é muito extenso, apenas uma página em que apresenta todas as informações pertinentes a disputa, por fim, o conceito substantivo apresentado no documento está atrelado as relações de trabalho nos castanhais, dando base para a construção da história local e regional. $\mathrm{O}$ documento "Artigo de Jornal" é sucinto, legível e expressa de maneira clara uma pequena notícia que visa apontar os garimpeiros como um perigo. A partir desse pequeno trecho podemos compreender como se constrói a imagem do garimpeiro e, de outros movimentos sociais, das milhares de pessoas que foram atraídas para região pelos projetos desenvolvimentistas e pela propaganda de ocupação da Amazônia e, em seguida se encontram em uma zona de conflitos, em que, resistir se torna uma das únicas opções.

Ainda ao utilizarmos esses documentos em sala de aula é possível aos alunos realizarem uma classificação e interpretação da linguagem e da estrutura do mesmo, identificando o tipo e a procedência. Assim no "Processo", por exemplo, pode ser identificado uma ação judicial pela forma como trás no início de seu texto uma saudação ao juiz responsável pela comarca de Marabá, como apresenta os sujeitos na condição de requerentes e requeridos e por conter a assinatura de um advogado ao final. Já no "Artigo de Jornal" é identificado como uma matéria em face a sua estrutura de narrativa que tem como o intuito a divulgação de informações de forma simples e sucinta, tendo em vista que o formato para o grande público, por isso muitas vezes se utiliza de bordões chamativos e grandes títulos para cativar o leitor de alguma maneira.

Em um terceiro momento é aconselhável que o professor faça a mediação de um debate entre os alunos e as fontes, priorizando a ação dos estudantes promovendo críticas ao documento na busca por questionamentos. Desse modo, é interessante que os alunos lancem alguns questionamentos às fontes, como: A) Com qual fim foi produzida esta fonte? B) Quais as intenções observadas no conteúdo que a fonte apresenta? C) Quais grupos do passado essa fonte nos ajuda a entender? D) Quais discussões históricas podem ser tiradas a partir da análise dessa fonte? E) Quais elementos históricos essa fonte apresenta? F) Quem a produziu? G) Quais sujeitos essa fonte descreve? H) Qual o período abordado pela fonte? Essas e outras questões que podem ser realizadas tem por função gerar uma maior proximidade dos alunos com o período histórico estudado e com os sujeitos históricos.

O documento aqui indicado de título, "Processo" traz a história de trabalhadores do período de exploração da castanha e foi produzido com o objetivo de registrar uma disputa judicial entre dois sujeitos que estiveram ligados por uma relação de trabalho. Com esse documento é possível abordar a forma como se organizavam os diversos trabalhadores em torno da castanha, as relações que eram estabelecidas entre eles e, os serviços prestados que contribuíram para a construção da região.

A notícia presente no documento "Artigo de Jornal" foi publicada perto do fim da ditadura, a região já estava associada a um forte poder militar, tendo em vista a Amazônia como uma região de fronteira, que há dez anos tinha vivido a Guerrilha do Araguaia e, onde ainda ocorria um forte movimento de combate à esquerda que estava ocorrendo em paralelo a diversos embates agrários, o garimpo em Serra Pelada, surge em meio a esses acontecimentos.

Serra Pelada é pensada justamente na perspectiva dos diversos projetos desenvolvimentistas aplicados a região, o fluxo migratório, as propagandas governamentais, as construções de rodovias e, como isso desencadeia uma série de fatores de mudança na região que atualmente ainda não 
foram resolvidos. É preciso compreender o quão violento foram esses projetos, apesar dos diversos interesses, acabam por penalizar os trabalhadores, em uma conexão entre o passado e o presente, tendo em vista os movimentos de resistências e os embates que têm vez nos dias de hoje. A narrativa apresentada no documento "Artigo de Jornal” está marcada pelo declínio da extração manual do ouro em Serra Pelada, que já era extremamente pressionada por iniciativas privadas e pelo poder público, como as ações promovidas pela Companhia da Vale do Rio Doce em parceria com o Estado e em consonância com a elite local que ansiava pela expulsão dos garimpeiros.

Airton dos Reis Pereira (2013) discute sobre essa resistência no sul e sudeste do Pará, que ocorre não como uma simples alternativa, mas como a única possível. As pessoas largaram tudo para irem para a região em busca de uma vida melhor, o garimpo é um exemplo forte dessa resistência, que apesar das diversas dificuldades estavam ali lutando pelo não fechamento do garimpo porque não poderiam voltar para casa sem nada, o sonho do ouro persistia. Acreditamos que não tem como pensarmos a história da região sem pensar nesses diversos projetos e suas consequências que engrenam a construção da cidade de Marabá.

É preciso levar aos alunos a compreensão de como foram implantadas essas atividades econômicas, tendo em vista que, nos dois casos a população local foi intensamente afetada por um conjunto significativo de mudanças. Outra realidade local passou a ter vez, mudanças sociais, ambientais, econômicas e culturais ocorreram, em boa medida trouxeram uma desorganização ao modo de vida das comunidades tradicionais da Amazônia. Cisões no modo de viver, rupturas nas relações tradicionais de trabalho, distanciamento dos meios de produção foram promovidos em um curto espaço de tempo. Os alunos do ensino fundamental e médio da região do sudeste e sul do Pará vivem em uma sociedade que é resultante destas mudanças.

Em um quarto momento do trabalho com fontes históricas em sala de aula, indicamos a exposição de pontos importantes na composição das fontes, procurando estabelecer uma relação entre a história em menor e maior escala.

A fonte "Processo" está inserida em um contexto de auge da exploração da Castanha na região de Marabá, sendo que a ocupação territorial da região e, a criação de alguns municípios ocorreram por conta de tal atividade que aumentou em muito o valor das terras na região, acarretando o cercamento de grande áreas por parte de poucos proprietários e a expulsão de grupos populacionais que não tinham a posse da terra.

A ação judicial, ora apresentada trás como marco uma disputa que remete às relações de trabalho, possibilitando observar as diversas profissões e dialogando em torno de uma mesma atividade econômico que contribuiu significativamente para a construção do que hoje é a região Sul e Sudeste do Pará. A exploração da Castanha ganha força após a queda do ciclo da borracha, que causa uma crise econômica ao estado do Pará e ao Brasil. Desse modo, a Castanha vem como uma renovação da economia paraense e brasileira, ao ganhar força no mercado internacional e ocupar um dos primeiros lugares entre os produtos para exportação e consequente valorização das terras.

É por meio destas quatro ações propostas acima que indicamos um caminho de análise para as fontes escritas, iniciando pela: 1 - problematização de temas naturalizados; 2 - análise dos critérios sobre a estrutura dos documentos; 3 - reflexão e crítica por parte do aluno, ao documento na busca por questionamentos; 4 - exposição de pontos importantes na composição das fontes. Tal caminho tem por função auxiliar o professor de história do ensino básico e médio que poderá utilizar em sala de aula os documentos ora indicados, ou outros que abordem passagens da história local. Em muitos casos essas estão intimamente relacionadas as vivências dos alunos e de seus familiares, possibilitando diálogos e leituras que auxiliam na reflexão entre o passado e, o presente, 
assim abonando o sentido dos estudos históricos na construção da cidadania.

\section{Considerações finais}

As questões principais que podem reger os temas de aulas aqui propostos passam pelas mudanças econômicas geradas pela exploração dos recursos naturais da Amazônia e pelos projetos desenvolvimentistas que tiveram vez na região, assim como, as mudanças acarretadas, na busca de como suas narrativas interferiram na construção das espacialidades locais.

Até hoje a cidade de Marabá que é o centro econômico do sul e sudeste do Pará tem os adjetivos "novo" e "nova" para marcar boa parte de seus bairros, nessa perspectiva o sonho da mudança, de uma nova realidade econômica se transmutou em uma espacialidade da desordem, tendo em vista que, muitos dos que foram expulsos das terras pelas consequências geradas pelas atividades da castanha e, pelos projetos desenvolvimentistas, acabaram por serem deslocados para essa cidade. Ali ocuparam áreas de forma desordenada, são seus filhos e netos que hoje estudam nas escolas do município, de tal modo, poderão refletir sobre essa história regional em suas aulas de história, certamente, esses temas já fazem parte da consciência histórica desses jovens por meio das memórias familiares, o uso das fontes históricas em sala poderá dialogar com essas múltiplas memórias locais na busca por uma compreensão de suas vivências.

Pensamos o ensino de história local como um forte elo para a construção de uma identidade local, mas sem perder de vista o sentido nacional. O uso do documento já não possui o caráter de verdade defendido pelo positivismo, tal concepção contribui para mudanças nas produções historiográficas e cada vez mais deve estar relacionada ao ensino de uma história plural.

\section{Fontes}

Arquivo Histórico Manoel Domingos. Acervo da Fundação Casa da Cultura de Marabá.

Centro de Referência em História e Memória do Sul e Sudeste do Pará. Universidade Federal do Sul e Sudeste do Pará - Marabá-PA.

\section{Referências}

ALMEIDA, Rogério de. Cinema e Educação: fundamentos e perspectivas. Educ. rev. [online]. Belo Horizonte. V.33, p. 1-28, 2017.

ANUNCIAÇÃO, Ana Paula; SPERANDIO, Amábile. Aula-oficina: uma proposta de utilização de documentos históricos em sala de aula. História \& Ensino, Londrina, v. 18, p. 131-156, especial, 2012.

BITTENCOURT, Circe Maria Fernandes. Usos Didáticos de Documentos. IN: Ensino de História: Fundamentos e Métodos. $2^{\text {a }}$ ed. São Paulo, 2008.

CAIMI, Flávia Eloisa. Fontes históricas na sala de aula: uma possibilidade de produção de conhecimento histórico escolar? Anos 90, Porto Alegre, v. 15, n. 28, p. 129-150, dez. 2008.

CARVALHO, Marieta Pinheiro de; ZAMPA, Vivian Cristina da Silva. O Arquivo Nacional na "sala de aula": fontes históricas na construção do conhecimento. Revista História Hoje, v. 6, n 12, p. 35- 
54, 2017.

CHAVES, Elisgardenia Oliveira. Educação patrimonial e ensino de história: potenciais do uso de documentação arquivística. História \& Ensino, Londrina, v. 19, n. 2, p. 59-85, jul./dez. 2013.

CORREIA, Janaína dos Santos. 0 uso de fontes no ensino de história: o livro Úrsula de Maria Firmina dos Reis na busca pelo escravo real. História \& Ensino, Londrina, v. 18, n. 2, p. 179-201, jul./dez. 2012.

GUERRA, Fabiana de Paula; DINIZ, Leudjane Michelle Viegas. A incorporação de outras linguagens ao ensino de história. História \& Ensino, Londrina, v. 13, p. 127-140, set. 2007.

LARA, Sílvia Hunold. Os documentos textuais e as fontes do conhecimento histórico. Anos 90, Porto Alegre, v. 15, n. 28, p. 17-39, dez. 2008.

MONTI, Carlo G. DAMASCENO, Chrislaine Janaína. A representação dos povos indígenas do Brasil no livro didático de história Projeto Araribá. ESCRITAS. V. 11, n. 2 (2018). p.99-121.

NASCIMENTO, Evandro Cardoso do. Educação patrimonial e ensino de história na Ilha do Mel. História \& Ensino, Londrina, v. 21, n. 1, p. 253-269, jan./jun. 2015.

NETO, André de Faria Pereira. 0 uso de documentos escritos no ensino de história: premissas e bases para uma didática construtivista. História \& Ensino, Londrina, v. 7, p. 147-165, out. 2001.

OLIVEIRA, Lélio Luiz de. História Regional: ensino e pesquisa. Dialogus (Ribeirão Preto), v. 7, p. 926, 2012.

OLIVEIRA, Sandra Regina Ferreira de. Sete categorias de perguntas e a interpretação de fontes históricas no terceiro grau. História \& Ensino, Londrina, v. 8, edição especial, p. 215-229, out. 2002.

ORTA, Daniel Augusto Arpelau. Nos trilhos da cultura ferroviária: documentos de arquivo familiar no ensino de história. História \& Ensino, Londrina, v. 13, p. 71-89. 2007.

PEREIRA, Airton dos Reis. A luta pela terra no sul e sudeste do Pará: migrações, conflitos e violência no campo. Recife, 2013. 265 f. Tese (doutorado) - UFPE, Centro de Filosofia e Ciências Humanas, Programa de Pós-graduação em História, 2013.

PEREIRA, Nilton Mullet; SEFFNER, Fernando. 0 que pode o ensino de História? Sobre o uso de fontes na sala de aula. Anos 90, Porto Alegre, v. 15, n. 28, p. 113-128, dez. 2008.

PINSKY, Carla Bassanezi (org.). Fontes históricas. São Paulo: Contexto, 2005.

PORTUGAL, Ana Raquel Marques da Cunha Martins. A utilização de histórias em quadrinhos no ensino de história. Revista Camine. 2015, v.7, n.2.

RIBEIRO, Renilson Rosa. Entre textos e práticas: ensino de história, instituição escolar e formação docente. História \& Ensino, Londrina, v. 21, n. 2, p. 151-179, jul./dez. 2015.

ROLIM, Rivail Carvalho. 0 uso do jornal para trabalhar com a noção de fato e tempo histórico. História \& Ensino, Londrina, v. 8, p. 63-84, out. 2002.

SCHMIDT, Maria Auxiliadora, CAINELLI, Marlene. Ensinar História - Col. Pensamento e Ação na sala de aula. $2^{a}$ ed. São Paulo: Scipione. 2009.

SILVA, IDELMA SANTIAGO DA; POSSAS, H. M. Na Rota da 'Transa-Amazônica'. Fenix: revista de história e estudos culturais, v. 12, p. 1-15, 2015.

VALE, Hardalla Santos do; ARRIADA, Eduardo; CLARO, Lisiane Costa. A utilização de fontes no 
ensino de história: a imprensa na construção do conhecimento. Momento, Rio Grande, v. 20, n. 1, p. 59-72, 2010.

Artigo recebido em: 16/01/2019

Artigo aceito em: 16/04/2019 